\title{
TRAINING OF AFGHAN STUDENTS IN EDUCATIONAL INSTITUTIONS OF THE UKRAINIAN SSR IN THE 1980-S (ON THE EXAMPLE OF KIROVOHRAD)
}

Abstract. Introduction. Within the framework of the "socialist orientation" policy, pursued by the USSR in the Democratic Republic of Afghanistan in the 1980s, an important place was given to the reorganization of the system of education due to the Soviet model. An important role in the education of Afghan youth in the spirit of the "ideals of the April Revolution" was given to the education of Afghans in educational institutions of the Soviet Union.

The purpose of this article is to study the issue of training Afghan students in the Ukrainian SSR on the example of educational institutions in Kirovograd and to clarify its place in the structure of the socialist transformation of Afghanistan in the 1980-s.

The research methodology is based on content analysis of historical sources, problem-chronological, typological, retrospective methods.

Main results and conclusions. During the Cold War the education of citizens of "third world" countries in Soviet educational institutions was an effective element of policy aimed at promoting the interests of the USSR in the world. During the years of such purposeful work, thousands of qualified specialists of various specialties for Afghanistan have been trained in Soviet higher and vocational schools. At the same time, a whole generation of Afghans had been brought up and who, after studying in the Soviet Union, became the bearers of the "Marxist-Leninist worldview," sincerely admired the Soviet reality and wanted to transfer at least some elements of it to their homeland. Studying in the USSR in the 1960's and 1970's contributed to the spread of Marxist ideas in Afghanistan, which was embodied in the "April Revolution" of 1978. In the next decade the training of Afghans in the USSR was a means of forming a large pro-Soviet stratum of Afghan society under Soviet occupation,

Scientific novelty of research results. For the first time in Ukrainian historiography, the problem of educating the citizens of Afghanistan in educational institutions of the Ukrainian SSR in the 1980s as a component of the policy of "socialist orientation" has been studied. Based on a study of a wide documentary base, it was established that ideological and political education, instilling in them "Marxist-Leninist worldview" and "ideals of the April Revolution" was the main component of working with Afghan students.

Key words: Democratic Republic of Afghanistan, Ukrainian SSR, educational institutions, students, ideological-political education.

Одержано редакцією 15.04.2021

Прийнято до публікації 29.06.2021

УДК 94:504.06+323.1(477)"1986/1990"
DOІ: 10.31651/2076-5908-2021-1-97-105

\author{
PERGA Tetiana, \\ $\mathrm{PhD}$ in History, senior researcher, \\ State Institution "Institute of World \\ History of National Academy of \\ Science of Ukraine" \\ Orcid ID: 0000-0002-8725-3451 \\ e-mail: pergatatiana@gmail.com
}

\section{ECO-NATIONALISM, "GREEN WORLD" ASSOCIATION AND PATH TO THE INDEPENDENCE OF UKRAINE IN LATE 1980s - EARLY 1990s}

Introduction. The problem of social activism in the Ukrainian SSR after the Chernobyl disaster is widely studied by researchers. American researcher J. Dawson developed the theory of eco-nationalism in the late 1990s, according to which a specific movement emerged in the "nuclear" Soviet republics eco-nationalism that combined ecological and national movements. She contends, however, that the two movements existed in parallel and their degree of convergence depended on the local context. Novelty. Although there are a number of studies on specific aspects of this theory, they are fragmented and the situation in the Ukrainian USSR has not been the subject of deep research. The purpose of the article is to investigate the social activism in Ukraine in the late 1980s - early 1990s taking the example of the Ukrainian environmental association "Green World». Methods. The study is based on an analysis of the original documents of the KGB and the Central Committee of the Communist Party of Ukraine and the memoirs of members of the association. Results. The Chernobyl accident was a catalyst for the general public's dissatisfaction with the Soviet government's policies in many areas. First of all, it led to the 
emergence of the anti-nuclear movement, which we identify with the environmental one. Important role in the emergence of environmental movement in Ukraine played creative intellectuals - writers who at the same time represented the ideas of cultural nationalism. The accident radically changed their views on nuclear energy and sparked a public debate on its prospects in the republic. At the initiative of the Union of Writers of Ukraine, the "Green World" Association was established. During 1987-1989, it started activities, hold many protests, adopted the program and strategy. "Green World" has become a leader of the environmental movement and an umbrella to unite disparate environmental informal groups. Conclusions. Although the association's official documents do not contain slogans of obvious nationalist orientation and it has chosen an ecological niche for its activities, we have found a number of facts that allow us to claim that it supported many nationalist actions and demanded expansion of the Ukrainian ethnic group's sovereignty in the USSR. Thus, it contributed to the spread of the eco-nationalism ideology and the shaking of the foundations of the USSR, which led to Ukraine's independence in 1991.

Key words: Ukrainian SSR, USSR, eco-nationalism, cultural nationalism, sovereignty, social activism, ecological movement, "Green World", creative intelligentsia.

Introduction. The discourse on the dissolution of the USSR and the emergence of new independent states in the early 1990s includes question on the role of eco-nationalism in this process. Eco-nationalism theory was developed in the early 1990s by the American researcher J. Dawson, who explored social activism in post-Soviet countries. She found a linkage between the anti-nuclear movements that had arisen in aftermath of the Chernobyl accident in some Soviet republics where nuclear reactors were located (Ukraine, Lithuania, Armenia and Russia) and national movements. The symbiosis of these movements contributed to the collapse of the Soviet Union in 1991 [1]. Since that time, this theory has neither been refuted nor developed.

Originality. Social activism that took place in many Soviet republics after Chernobyl accident has been explored from many perspectives. Most studies focus on the ecological (J. Stewart, C. Zieger, D. Marples, M. Friendly, A. Feshbach, A. Leukhina etc.) or national-cultural (T. Kuzio, D. Gorenburg, A. Shcherbak etc.) activism. S. Plohiy in the book "Chernobyl. A History of Tragedy" put certain attention to the transformation of eco-activism into eco-nationalism. $\mathrm{He}$ gave a rather critical description of the activists who tried to use the Chernobyl card in the realization of their political plans [2]. However, at the moment there are no in-depth studies of eco-nationalism in Ukraine, which actualizes the topic of this article.

Purpose. This paper aims to confirm or refute the theory of J. Dawson by the example of the environmental association "Green World", which was established in the Ukrainian SSR in the late 1980s. Te paper attempts to answer following questions: what is the role of the organization in promoting the ideology of eco-nationalism in the first years of its activities? Is it legitimate to speak of a merger of environmental and national movement in this period?

Methodology.This research is based on the analysis of archive materials of KGB and Communist Party of Ukraine (CPU) and the momories of the members of "Green World" association.

Results. The Chernobyl accident, which took place on April 26, 1986, played an important role in mobilizing the protest movement in Ukraine. It awakened many Soviet citizens and gave impetus to social activism. The behavior of the Soviet authorities, which tried to conceal the truth about the accident or to falsify it, various rumors, fear of many citizens for their lives and the lives of children, the emergence of the first data on other environmental problems contributed to this. In the late 1980s, environmental requirements (particularly antinuclear which we associate with environmental) became an integral part of the general democratic protest, facilitated by the deterioration of the socio-economic situation in the USSR and the growth of dissatisfaction with the totalitarian style of government and the strong centralization of power as well as highly limited sovereignty of the Soviet republics. As Jane Dawson states, "widespread antinuclear protests of the late perestroika period reflected an explosion of anger and resentment against Moscow's domination" $[1,4]$. However, in Ukraine, these protests began later than in Lithuania and Armenia, because of the stay in power of the First Secretary of the Central Committee of CPU V. Shcherbytsky, who slowed down the process of restructuring (perestroika) in Ukraine.

The environmental movement that began in Ukrainian SSR in the late 1980s had a number of features. In the USSR and the Ukrainian SSR, there was no environmental activism in the modern sense of the word prior to the Chernobyl accident. The Soviet Union denied the existence of environmental problems, which it considered to be the feature of capitalist countries. Ukrainian 
Society for Nature Conservation - USNC and Brigades (dryzhina movement) were controlled and managed by the Communist Party. Some Russian historians, such as Alexander Shubin [3, 3], believe that brigades were a refuge for the liberal-minded intelligentsia, which protested to the existing system. Even if we take his point of view into account, we cannot speak of the massive protest nature of this type of civil activism during this period.

It should also be emphasized that given the propaganda of a peaceful atom there was no antinuclear movement in the USSR and in the Ukrainian SSR before the Chernobyl accident. The Iron Curtain hindered the learning of experience of anti-nuclear movements in the West and no one understood the threat of nuclear for national development. Many Ukrainian writers influenced by Soviet propaganda praised nuclear energy as it brought economic benefits to the Soviet economy and improved the living conditions of Soviet citizens. Thus, V. Yavorivsky wrote the novel "Chain Reaction", I. Drach wrote poetry "The Breath of Atomic" etc. Only some Ukrainian writers and scholars attempted to protest the industrial plans of the Soviet authorities for hydrotechnical construction on the Dnipro River in the 1960s and 1970s (S.Plachynda, O. Honchar, O. Dmytrenko, O.Dovzhenko etc.) but they achieved nothing [4, 223].

What was the reason for the formation of the anti-nuclear movement in the Ukrainian SSR? In addition to the Chernobyl accident, it was also the ambitious energy strategy of the USSR that put the task to build between 1977 and 1989, 16 nuclear power reactors total capacity of 14,800 MWe. Five nuclear power plants were to build in Ukraine - Chernobyl, South-Ukrainian, Khmelnytsky, Rivne, Zaporizhzhya. In the mid-1980s, the idea of building two additional facilities - nuclear power station in the Crimea and Chygyryn was born [5, 2].

The peculiarity of the situation in Ukraine is that it was the Ukrainian writers (and not scientists) who first raised the question of the inadvisability of building such a number of nuclear plants in the republic. As Yu. Shcherbak recalled, I. Drach was very worried when the accident occurred. Apparently, some writers felt guilty about this, as in previous years glorified the construction of the Chernobyl station [6, 51]. In 1987, Yu. Scherbak wrote a poem "Chornobyl", in 1988, I.Drach - a poem "Madonna of Chernobyl", V.Yavorivsky - "Mary with wormwood at the end of the century". They showed the tragedy that occurred in Chernobyl. Since writers considered moral authority in the Soviet Union, their position on the issue of nuclear power had a great influence on the formation of a broad protest movement in Ukraine, involving scientists, human rights and civil society activists and a wide range of people.

The first step in the institutionalization of anti-nuclear activism was done on July 1986, when one of the Ukrainian representatives at the Congress of Soviet Writers in Moscow, the poet B. Oliynyk, spoke openly about the lessons of the Chernobyl disaster. He declared, "Chernobyl has forced us to rethink a great deal, including the fact that the common metaphor of "the peaceful atom" is only a metaphor" [7, 2]. The construction of a nuclear power plant near Chygyryn was of particular concern to writers. On the one hand, it was a historical place - the capital of Ukrainian hetmans and, on the other hand, its location near Dnipro river threatened in the case of any disaster to pollute territory of the whole Ukraine. Famous Ukrainian writer O. Honchar called it "another Chernobyl." His protest appeared in a letter signed by seven Ukrainian writers dated August 6, 1987, where they demanded to stop the construction. At national conference of creative intelligentsia held in Leningrad on October 1, 1987 he called against the construction of nuclear power plants near Chygyryn and on Crimea and blocking of the Dnieper-Bug lima which could cause destruction of the environment. His speech that first was published in the newspaper "Literaturna Ukraina" on October 7, 1987, was repeated with some restriction in "Literaturnaya Gazeta" on December 9, 1987 [6, 2]. Activities of the Ukrainian writers was supported by some researchers. On January 21, 1988 "Literaturna Ukraina" published a letter from 13 leading Ukrainian scientists, all of whom opposed the expansion of nuclear energy in Ukraine. This was the first public critique of the nuclear power program to come from academics $[8,3]$.

In late 1986, the Union of Writers of Ukraine established the environmental commission, which started to organize workshops dedicated to environmental issues: "How and where the rotary wheel rolls", "Who will become the master and savior of the Dnieper?", "Nuclear energy alternatives". They were conducted by writer S. Plachinda and were very popular. In April 1987, commission organized a small conference devoted to environmental issues, primarily Chernobyl $[6,30,52]$. 
After it, an initiative group on creation of environmental association was established. It included writers (Y.Shcherbak, S. Plachinda, M.Vingranovsky, I. Drach, V.Knyazyuk); and staff of the National Academy of Sciences of Ukrainine (Head of the Department of the Institute of Botany D.Grodzinsky; Scientific Secretary of the Council of Research of Productive Forces S.Dudka; Head of the Department of the same Institute B.Piraishvili; Chief Engineer of the Institute of Physics O.Kovalenko; researcher of the Institute of Oncology A. Petik; Head of the Department of Geography V. Poleshchuk; Head of the Department of the Odessa Institute of Economics V.Stepanov). It was decided to establish an independent Ukrainian association "Green World" instead of joining "Ecology and Peace" group formed in Moscow. In his memoirs, the writer S.Plachinda recalls that "Green World" was born from turbulent evenings in "Union of Writers of Ukraine" [6, 30].

In December 1987, the association "Green World" was officially registered under the umbrella of the republican Committee for the Peace Protection and became the first environmental NGO in Ukrainian SSR. Writer S. Plachinda was elected the head of the organization. The deputy chief was V. Sahaev, and the executive secretary was S. Dudko. The Committee for the Peace Protection (later Ukrainian Peace Council) under the leadership of the outstanding writer O. Gonchar provided enormous assistance in organizing the work of "Green World". The Committee provided a room, a meeting room, an address for correspondence, office equipment and even financed some activities and travel. These resources were of great value in late 1980s as only party elite had access to them in the Soviet Union. This contributed to the widespread of activities of "Green World". The resource-mobilization theory put resources at the center of both the emergence and success of social movements [9]. The example of the "Green World" demonstrates the validity of this statement.

At the end of 1987, "Green Council" was elected, which was to work in the break between congresses. It included 40 members, mostly writers and scholars. The best-known figures are writers - D. Pavlichko, I. Drach, Yu.Yavorivsky, B. Oliynyk; human rights defenders - dissidents V. Chornovil, S. Naboka, A. Shevchenko; academics - D. Grodzinsky, S. Shestopalov, E. Yakovlev and other well-known scientists, artists and famous public figures [6, 85].

It should be noted that at the same time writers began to put forward some requirements of a national character. As early as the early 1970s, when V. Shcherbitsky became the First Secretary of the CPU, another wave of Russification began in the republic. In June 1987, the plenary of the Union of Writers of Ukraine appealed to the central party bodies and the Presidium of the Supreme Soviet of the Ukrainian SSR with the demand to improve the position of the Ukrainian language, expand scope of its application and raise the level of its using in the mass media. In 1988, criticism of V.Shcherbitsky began to be heard, because he delayed the restructuring processes in Ukraine. This move of writers was of great importance for the development of the national movement in Ukraine, as the issue of language was considered in the USSR as a manifestation of cultural nationalism. In fact, a new stage of the national liberation struggle started in Ukraine.

These facts demonstrate that Ukrainian writers - people who people who openly raised the issue of expanding the sovereignty of the Ukrainian ethnic group initiated the emergence of wide environmental movement. Demands to limit the construction of nuclear power plants and expand the use of the Ukrainian language in the republic began to be seen as equal components of the struggle for the expansion of the rights of the republic within the USSR. Therefore, cultural and environmental nationalism had some common interests.

Various informal groups began to form spontaneously in Ukraine. The policy of perestroika and publicity pursued by the First Secretary of the CPSU Central Committee M. Gorbachev helped to create a space for communication, exchange of views and debates, which accelerated social mobilization. By 1989, there were established 6957 socio-political, 1460 cultural and historical and 1946 ecological informal groups in Ukraine [10]. The most active were the following: 1) environmental groups "Green Charity", "Ecology", "Noosphere", "For Ecological Restructuring", "Not Indifferent", "Noosphere", "Association of Environmental Initiative"; 2) national-cultural groups "Spadshchina", "Society "Lion", student organization "Gromada", "Society of the Ukrainian language named after Taras Shevchenko", historical-educational organization "Memorial", "Club of Ukrainian language lovers", "Fraternity of students" etc. They began to organizenumerous spontaneous protests and rallies. 
It is noteworthy that the first officially sanctioned by the authorities rally took place in Kyiv on 13 Novenmer 1988, and was devoted to environmental issues. At these meetings, various issues were discussed [11]. Very often environmental rallies ended with demands to expand the use of Ukrainian language and symbols, and national rallies ended with calls to stop the construction of new nuclear plants. There are some examples. At the ecological rally in the village of Vinniki, Lviv region in September 1989, 3000 participants demanded political and economic autonomy of Ukraine, adoption of an alternative bill on elections to the Supreme Soviet, and giving the Ukrainian language the status of a state language [12]. At the Kiev rally, which was organized by the informan public groups "Sadshchina", "Noosphere", "Gromada" and "Green World", in addition to demands for the elimination of nuclear power plants and chemical enterprises in Ukraine, there were also demands for a nationwide referendum on elections to the Supreme Soviet of the USSR. These examples demonstrate a combination of environmental, democratic and national requirements in public protests in Ukraine in the late 1980s.

The point of their convergence was dissatisfaction with the restriction of rights of Ukrainians - the titular nation that inhabited Ukrainian SSR in the economic, political and cultural fields and the model of governance in the USSR, which imposed to the republics decisions adopted in Moscow. In particular, this concerned decisions on the use of national natural resources, which caused their deterioration.

In the spring of 1989, the first Republican conference of "Green World" took place, which started to develop strategy and tactics of ecological movement in Ukraine. 170 delegates included 54 people from 17 regions of the republic, representatives of the Ukrainian Cultural Club, Ukrainian Helsinki Union, Ukrainian Christian Democratic Partyand invited guests from the cities of Kurgan (Russia), Minsk (Bilorus), Tbilisi (Georgia) as well as journalists from Norway visited the conference according to the information of KGB. Corresponding Member of National Academy of Science of Ukraine D. Grodzinsky made a report. By the way, KGB estimated the report as constructive. Reporter made a critical analysis of the situation in some regions and in the republic as a whole, and shared the experience and difficulties of the practical work of the environmental groups on the ground. He criticized the obstacles to the environmental rallies hold in Poltava, Kalush, Ivano-Frankivsk, Kremenchug, Poltava, Truskavec, Lviv, Slavuta and Shepetovka, revealed the possibilities and tasks of public in improvement of environmen. More than 40 people participated in the discussion of the report. Energetic support was expressed for the cessation of further construction of the nuclear power plants in Ukraine, the declassification of information on the working nuclear power plants, the radiation contamination, the state of health of the population in the areas affected by the Chernobyl nuclear power plant, the provision of radiometers and the nitratometers to the population.

Representatives of Georgia, Bilorus and Russia addressed the conference. They told about the merger of the party and state apparatus, the indecent behavior of many members of the party apparatus who immediately after Chornobyl accident evacuated their relatives, necessity to review the existing system. Conference called for the creation of an environmental union as an alternative to the Council of Ministers of the USSR [13, 41-46].

The draft of Charter of association was adopted at the conference. It declared main purpose of the association - involvement of the public in solving environmental problems through ideas of survival, democracy and humanism, promotion the right of the Soviet citizens to a healthy habitat, which is one of the inalienable human rights [14].

At that time, the environmental movement was fragmented. Attempt to coordinate environmental activism took place during the first All-Ukrainian congress of "Green World" on October 26-28, 1989 in Kiev. In the introductory speech the academic-writer, deputy of the Supreme Soviet of the USSR O. Gonchar called "greens" to participate in elections to the Councils the Soviet Deputies of all levels, and take an active part in the preparing of environmental laws, thereby influencing decision-making in the environmental policy. The official political slogan of the Association became the words "Survival. Democracy. Humanism". The Congress attended 301 delegates from all regions of the republic and 89 - from Kyiv, 270 guests - scientists, writers, representatives of state, party and public organizations of the republic, as well as from Moscow, Belarus, Kazakhstan, and the Baltic republics. There were 31 journalists and foreign guests who represented Great Britain, USA, Netherlands, Sweden, Czechoslovakia, "Green Peace International”. 
Congress approved the program and the charter. The programme of "Green World" included the demand for halting the development of nuclear energy in Ukraine and development of options for the rapid closure of the Chernobyl nuclear power plant. The need to adopt nuclear energy laws and to provide social, medical and other assistance to victims of environmental accidents and catastrophes were highlighted [15, 103-105]. The following principles of activities were proclaimed: the priority of ecology over economics and politics, democracy and publicity in the field of ecology, public participation in environmental issues, a combination of scientific and humanistic principles, the greening of education. Association stated the support to the ongoing restructuring and democratization of society, the activities of all democratic forces of society $[16,2]$.

The Congress elected the governing bodies - the "Green Council" that included about 100 people, including 45 from Kiev, a Board of Experts and the Environmental Foundation headed by D. Grodzinsky. The newspaper "Green World" was established. Doctor of Medical Sciences and social activist, author of "Chernobyl" novel Yu. Shcherbak, who was the secretary of "Union of writers of Ukraine", was elected the chair of the association. A. Panov was elected a full-time Executive Director. The Deputy and Secretary became the Biologist, Candidate of Sciences Yu. Mishchenko [15, 107-108]. Thus, a definite coordination center for the environmental movement and its main directions was formed.

The activities of the "Green World" reflects the diversity of the Ukrainian environmental movement in the late 1980s. On the one hand, numerous informal environmental groups began to unite under its umbrella. Through access to the resources given by Peace Committee and later by perestroika (possibilities of meeting, publishing the newspaper "Green World", support of many public figures and Ukrainian diaspora etc.) association had become the largest in Ukraine. Its brand was very popular and many environmental groups used it to promote themselves. In turn, this extended the influence of "Green World". The easy entry procedure, which required only an application from a potential candidate, contributed to the increase in membership of the organization.

Official registration of association by the Soviet authorities simplified its activities because many local authorities allowed it to organize rallies. In Ukrainian archives there are many notes of officials of KGB and CPU on its activities. For example, in the fall of 1989, members of association organized a rally in Netishyn; in May 1990 - in Enakievo; in September 1990 - in Kiev etc. In Netishyn, except ecological, issues of national symbols, discussion of the draft Law on Elections of People's Deputies were raised [17]. A letter from the Secretary of the Nikolaev Regional Committee of the CPU to the First Secretary of CPU V. Shcherbitsky stated in spring of 1989, that for two years "Green World" had influence on the local population that oppose the expansion of the construction of the South-Ukrainian NPP and hydraulic complex on the Southern Bug River"'[18].

Since the organization brought together people with different views, some of them supported nationalist positions. As a member of "Green World" Yu. Samoilenko remembers, that in the late 1980s, there were several wings: one insisted on the priority of solving the environmental problems, other considered the main development of the Ukrainian state (so-called eco-patriots). He considered that the second direction was chosen as a priority $[6,33]$.

Of course, one can find manifestations of nationalism in activities of the association. The main connection - some writers, who initiated the activities of "Green World" and contributed to its activities in 1987-1989. More, during meetings of "Green World" the idea of establishing "People's Movement for Perestroika" - similar to those have just started to be created in Latvia and Estonia appeared (later the movement transformed to the "People's Movement of Ukraine" (RUKH) - centre-right political party of nationalistic orientation). This idea was announced by writers - the first chairman of association S. Plachinda and its members - I. Drach, D. Pavlichko at the first sanctioned by the authorities rally on environmental issues held in Kiev on November 13, 1988 [11]. "Green World" actively cooperated with RUKH and participated in all its actions. It was even an idea to turn it into ecological wing of RUKH. The leader of RUKH V. Chornovil tried to realize this idea in the summer of 1989 but failed.

The organization refused to develop in a nationalist framework and chose the niche of ecology. As Yu. Scherbak stated the main reason for this was the strategy to attract a wide range of Ukrainians under the umbrella of the organization. At that time, not all of its members were ready to support 
nationalism, and while many of them were in favor of independence idea, they feared of high politicization of the "Green World". Therefore, in the following years the "Green World" association, like the environmental movement, developed separately from the national-cultural movement. At the same time, it used some democratic slogans to attract more supporters, such as the liquidation of the colonialist institutions, the demilitarization of the economy, and taking into account the local population's thoughts when establishing enterprises on the territory of Ukraine. Many members of the association decided to take part in elections to the Supreme Council of Ukraine in 1990. As local authorities prevented "Green World" representatives from registering as candidates, this led to a new wave of protests in 1989-1990 [19]. Despite this, many activists, who used environmental slogans in their preelection programs, won elections to central and local authorities, as environmental protection was a hot and popular topic for the electorate.

Conclusion. Writers who expressed the ideology of cultural nationalism played a major role in the emergence of the environmental movement in the Ukrainian SSR, particularly in the creation the most influential environmental organization of the late 1980s - "Green World". However, the organization chose an environmental niche for its activities, although it used some national and democratic slogans to attract supporters and voters. This can be explained by the restriction of the rights of the Republic to take important decisions, including environmental ones. As a result, the improvement of the environmental situation was directly linked to the change in the political system in the USSR. Therefore, although the organization did not include obvious nationalist slogans in its program and strategy, it periodically supported activities of nationalistic groups in 1988-1990. In addition, the demand to stop the construction of new nuclear power plants, taking into account the interests of the Republic in the construction of new industrial facilities and allow the public to participate in the important to the Ukrainian ethnic group decisions were aimed at expanding the sovereignty of the Republic in the USSR. Due to the high popularity of the association, these ideas were popularized among the Ukrainians. It can therefore be concluded that the organization has contributed significantly to the erosion of the foundations of the Soviet Union, its disintegration in 1991 and the proclamation of the independence of Ukraine, as well as to the popularization of the ideology of eco-nationalism.

\section{Список використаної літератури}

1. Dawson, J. Eco-nationalism: Anti-nuclear activism and national identity in Russia, Lithuania, and Ukraine / J. Dawson. - Durham, NC: Duke University Press, 1996. - 221 p.

2. Plohiy S. Chernobyl. A History of Tragedy / S. Plohiy. - Westminster: Penguin, 2019. - 435 p.

3. Экологическое движение в СССР и вышедших из него странах / Экологические организации на территории бывшего СССР. - Москва: «Рау-пресс», 1992. - 145 с.

4. Горло Н. Вплив гідробудівництва на Дніпрі на соціальну фсеру Наддніпрянщини (50-70-ті pp. ХХ ст.) / Н. Горло // Україна в ХХ ст.: критика, ідеологія, політика. - 2008. - №14. - С.221-231.

5. Nahaylo B., Opposition mounts in Ukraine to nuclear energy program / B. Nahaylo // The Ukrainian weekly. - 1988. - №3. - P.2.

6. Зелена хвиля незалежності. Українська екологічна асоціація «Зелений світ» / За редакцією Ю.Самойленко. - Київ: Видавництво «Український патріот», 2017. - 267 с.

7. Nahaylo B., Opposition mounts in Ukraine to nuclear energy program / B. Nahaylo//The Ukrainian weekly. -1988 . - №2. - P.2.

8. Який прогноз на завтра? Атомна енергетиа в Україні /Літературна Україна - 1988. - № 3. - Р. 3.

9. Jenkins J.C. Resource Mobilization Theory and the Study of Social Movements / J.C. Jenkns // Annual Review of Sociology. - 1983. -Vol.9. - P. 527-553.

10. Про роботу партійних комітетів республіки з самодіяльними громадськими організаціями / ЦДАВУ, Ф. 1, оп.32, справа 2874, арк.76.

11. Інформаційне повідомлення КДБ УРСР до ЦК КПУ від 14.11.1988 p. “О состоявшемся в г. Киеве митинге по проблемам экологии” [Електронний ресурс]. - Режим доступу: http:// avr.org.ua/viewDoc/11231/

12. Інформаційне повідомлення КДБ УРСР до ЦК КПУ від 25.09.1989 р. “О митингах, шествиях и молебнах в Крымской, Львовской и Ивано-Франковской областях”, “К обстановке на шахтах Червонограда" [Електронний ресурс]. - Режим доступу: http://avr.org.ua/viewDoc/11248/

13. Про республіканську конференцію асоціації “Зелений світ” / ЦДАВУ, Ф.1, оп.32, справа 2611, арк.41-46. 
14. Статут Української екологічної асоціації «Зелений світ» // Літературна Україна. - 1990. - №16. - С.3.

15. Доповідна КДБ УРСР “Про з’їзд Української екологічної асоціації “Зелений світ” / ЦДАВУ, Ф.1, оп.32, справа 2611, арк.103-108.

16. Хто ми? / Зелений світ. - 1989. - №2. - С.2.

17. Інформація про проведення екологічного мітингу в м.Нетішин / ЦДАВУ, Ф.1, оп.32, справа 2555 , арк.95.

18. Лист секретаря Миколаївського обкома Компартії України Щербицькому В.В. №85 від 19.04.1989 р. / ЦДАВУ, Ф.1, оп.32, справа 2611, арк.115.

19. Про оперативну обстановку в республіці 15 січня 1990 р. / ЦДАВУ, Ф.1, оп.32, спр. 2873, арк.36.

\section{References}

1. Dawson, J. (1996). Eco-nationalism: Anti-nuclear activism and national identity in Russia, Lithuania, and Ukraine. Durham, NC: Duke University Press.

2. Plohiy S. (2019). Chernobyl. A History of Tragedy. Westminster: Penguin

3. Ecological movement in the USSR and the countries, which have left it (1992). In Ekologicheskiye organizatsii na territorii byvshego SSSR. Moscow: "Rau-press" (in Rus.).

4. Horlo N. Influence of hydraulic engineering on the Dnieper on the social sphere of the Dnieper region (50s - 70s of the XX century) (2008). Ukraina v KhKh st.: krytyka, ideolohiia, polityka, 14, pp.221-231 (in Ukr.).

5. Nahaylo B. (1998). Opposition mounts in Ukraine to nuclear energy. The Ukrainian Weekly, 3, p.2.

6. Green wave of independence. Ukrainian Ecological Association "Green World" (2017). Kyyiv: vydavnytstvo "Ukrayins№kyy patriot" (in Ukr.).

7. Nahaylo B. (1988). Opposition mounts in Ukraine to nuclear energy program. The Ukrainian weekly, 2.

8. What is the forecast for tomorrow? Nuclear energy in Ukraine (1988). Literaturna Ukrayina 3, p.3 (in Ukr.).

9. Jenkins J.C. (1983). Resource Mobilization Theory and the Study of Social Movements. Annual Review of Sociology, 9, pp. 527-553.

10. About work of party committees of the republic with amateur public organizations (1989). TSDAVU, F. 1, op.32, sprava 2874, ark.76 (in Ukr.).

11. Information message of the KGB of the Ukrainian SSR to the Central Committee of the Communist Party of Ukraine dated November 14, 1988 "On the rally on environmental issues held in Kyiv" (1988). Retrieved from: http://avr.org.ua/viewDoc/11231/ (in Ukr.)

12. Information message of the KGB of the Ukrainian SSR to the Central Committee of the Communist Party dated September 25, 1989 "On rallies, processions and prayers in the Crimean, Lviv and Ivano-Frankivsk regions" and "On the situation in the mines of Chervonohrad" (1989). Retrieved from: http://avr.org.ua/viewDoc/11248/ (in Ukr.)

13. About the republican conference of the Green World Association (1988). TSDAVU, F.1, op.32, sprava 2611, ark.41-46 (in Ukr.).

14. Statute of the Ukrainian Ecological Association "Green World" (1993). Literaturna Ukrayina, 16, 3 (in Ukr.).

15. Report of the KGB of the Ukrainian SSR "On the Congress of the Ukrainian Ecological Association" Green World (1989). TSDAVU, F.1, op.32, sprava 2611, ark.103-108 (in Ukr.).

16. Who are we (1989). Zelenyy svit, 2, p.2 (in Ukr.).

17. Information on holding an environmental rally in Netishyn (1989). TSDAVU, F.1, op.32, sprava 2555 , ark.95 (in Ukr.).

18. Letter of the secretary of the Nikolaev regional committee of the Communist Party of Ukraine to Shcherbytsky V. №85 dated 19.04.1989 (1989). TSDAVU, F.1, op.32, sprava 2611, ark.115 (in Ukr.).

19. On the operational situation in the republic on January 15, 1990 (1990) TSDAVU, F.1, op.32, sprava 2873, ark.36 (in Ukr.).

Перга Тетяна Юріївна, кандидат історичних наук, старший науковий співробітник ДУ «нститут всесвітньої історії НАН України»,

e-mail: pergatatiana@gmail.com

\section{ЕКО-НАЦІОНАЛІЗМ, АСОЦІАЦЯ «ЗЕЛЕНИЙ СВІТ» І ШЛЯХ ДО НЕЗАЛЕЖНОСТІ УКРАЇНИ НАПРИКІНЦІ 1980-х - НА ПОЧАТКУ 1990-х рp.}

Bступ. Проблема сочіального активізму в Українській РСР після Чорнобильської катастрофи широко вивчається дослідниками. Американська дослідниия Дю. Доусон наприкіниі 1990-х років розробила теорію еко-націоналізму, згідно до якої в «ядерних» республіках СРСР виник особливий 
рух - еко-начіоналізм, який поєднував екологічний і начіональний рух. Водночас вона стверджує, щзо ці дві течії протестного руху існували паралельно, а ступінь їх конвергенції залежала від локального контексту.

Новизна. Хоча існує низка досліджень з окремих аспектів цієї теорії, вони фрагментарні й ситуація в Українській СРСР не стала предметом трунтовних досліджень.

Мета статті полягає у вивченні сочіального активізму в Украӥні кіния 1980-х - початку 1990-х років на прикладі діяльності украӥнської екологічної асоиіації «Зелений світ».

Методи. Дослідження базується на аналізі оригінальних документів КДБ і ЦК КПУ та спогадів членів асоиіачії.

Результати. Чорнобильська аварія стала каталізатором невдоволення широких кіл громадськості політикою радянської влади у багатьох сферах. У першу чергу, вона спричинила появу антиядерного руху, який ми ототожнюємо з екологічним. Біля витоків його формування в Українській РСР стояла творча інтелігенція-письменники, які одночасно були виразниками ідей культурного націоналізму. Аварія корінним чином змінила їхні погляди на атомну енергетику $i$ сприяла початку публічних дебатів з приводу ії перспектив в республічі. 3 інічіативи Спілки письменників України була створена асоиіація «Зелений світ». Протягом 1987-1989 р. відбулось організачійне оформлення ї̈ діяльності, прийнята програма і стратегія, асочіаџія провела багато протестів. «Зелений світ» перетворився на лідера екологічного руху та парасолькою для об'єднання розрізнених екологічних неформальних груп.

Висновки. Хоча в офіційних документах асочіачії відсутні гасла очевидного начіоналістичного спрямування й вона обрала екологічну нішу для своєї діяльності, ми виявили низку фактів, шо дозволяють нам стверджувати, щзо “Зелений світ” підтримував багато акцій націоналістів $i$ висувала вимоги, спрямовані на розширення суверенітету української етнічної групи в СРСР. Таким чином вона сприяла поширенню ідеології еко-націоналізму і розхитуванню основ СРСР, що привело до здобуття Україною незалежності у 1991 p.

Ключові слова: Украйнська РСР, СРСР, еко-націоналізм, культурний начіоналізм, суверенітет, соиіальний активізм, екологічний рух, «Зелений світ», творча інтелігенція.

Одержано редакцією 30.03.2021

Прийнято до публікації 29.06.2021

УДК 378.4.091(477+560)

DOI: 10.31651/2076-5908-2021-1-105-112
САГАН Галина Василівна, доктор історичних наук, професор кафедри всесвітньої історії Київського університету імені Бориса Грінченка. Orcid ID: 0000-0001-8301-849X e-mail: h.sahan@kubg.edu.ua,

ШУТОЧКІН Владислав Олександрович, студент Київського університету імені Бориса Грінченка Orcid ID 0000-0002-6023-1391 e-mail: voshutochkin.iff19@kubg.edu.ua

\section{НАЛАГОДЖЕННЯ ОСВІТНІХ ЗВ' ЯЗКІВ УНІВЕРСИТЕТІВ УКРАЇНИ 3 ТУРЕЧЧИНОЮ У ПЕРШ ДЕСЯТИЛІТТЯ ХХІ СТ.}

У статті здійснено комплексний аналіз ролі та місия українських університетів у налагодженні освітньої співпраці упродовж XXI cm. з Турецькою Республікою. Зроблено історичний огляд становлення відносин, які стали базою для налагодження сучасного освітнього співробітництва, а також зазначено перспективи подальшого розвитку контактів. На основі аналізу звітів українських вишів, науковиів та довідок дипломатичного представництва України в Туреччині, розкрито зміст співпраці, показано форми і напрями зв'язків, які розвивалася між закладами вищої освіти України з Туреччиною у ХХI cm.

Ключові слова: Українсько-турецькі зв'язки, освітня співпраця, культурні зв'язки, університет. 